\title{
Alteration of placental haemostatic mechanisms in idiopathic intrauterine growth restriction
}

\author{
Reggie G arcía-R obles ${ }^{1 *}$, Paola Andrea Ayala-R amírez ${ }^{1}$, A lejandra E spinosa², M ercedes 0 laya², \\ J uan Diego R ojas ${ }^{3}$, M artha Bermúdez ${ }^{1}$, J aime E duardo B ernal ${ }^{1}$ \\ IInstituto de Genética Humana, Pontificia U niversidad J averiana. B ogotá, D.C., Colombia. \\ 2D epartamento de Patología, Hospital U niversitario San I gnacio-Pontificia U niversidad J averiana. B ogotá, D.C., C olombia. \\ ${ }^{3}$ U nidad de M edicina M aterno Fetal, Departamento de Obstetricia y Ginecología. \\ Hospital U niversitario San Ignacio-Pontificia U niversidad J averiana. B ogotá, D.C., Colombia. \\ * rgarcia@javeriana.edu.co
}

Received: 01-07-2012; Accepted: 21-08-2012

\begin{abstract}
Intrauterine growth restriction is a complication of pregnancy with a high probability of perinatal morbidity and mortality. It appears to be caused by abnormal devel opment of placental vasculature. Haemostatic processes are important for the development of the placenta, and an imbalance between procoagulant and anticoagulant factors has been associated with risk of intrauterine growth restriction. O bjective. To eval uate coagulation abnormalities in placenta of pregnancies complicated with idiopathic intrauterine growth restriction. M aterials and methods. Five placentas from pregnancies with idiopathic intrauterine grow th restriction were compared to 19 controls. We performed gross and histological examination of the placenta. A nalysis was made of both mRNA expression by real-time PCR and protein by ELISA of tissue factor and thrombomodulin in placental tissue. R esults. Results based on histological evaluation were consistent with an increased prothrombotic state in placentas from pregnancies with idiopathic intrauterine growth restriction, and thrombosis of chorionic vessels was the most important finding. The study showed an increased expression of tissue factor protein $(p=0.0411)$ and an increase in the ratio of tissue factor/thrombomodulin mR N $(p=0.0411)$ and protein $(p=0.0215)$ in placentas from pregnancies with idiopathic intrauterine growth restriction. There were no statistically significant differences neither betw een cases and controls in the mRNA levels of tissue factor or thrombomodulin nor at the protein level of thrombomodulin. Conclusion. Evidence of alteration of local haemostatic mechanisms at the level of the placenta, including abnormal expression of tissue factor and tissue factor/ thrombomodulin ratio, in pregnancies that occur with idiopathic intrauterine growth restriction is presented.
\end{abstract}

K ey words: intrautherine growth restriction, tissue factor, thrombomodulin, placenta diseases.

\section{Resumen}

Alteración de los mecanismos hemostáticos de la placenta en restricción de crecimiento intrauterino idiopático. La restricción del crecimiento intrauterino es una complicación del embarazo con alta probabilidad de morbilidad y mortalidad perinatal, que parece ser causada por desarrollo anormal de la vasculatura placentaria. Los procesos hemostáticos son importantes para el desarrollo de la placenta y el desequilibrio entre factores procoagulantes y anticoagulantes se ha asociado con restricción del crecimiento intrauterino. O bjetivo. Evaluar el compromiso hemostático en la placenta de los embarazos complicados con restricción del crecimiento intrauterino idiopática. Materiales y métodos. Se estudiaron cinco placentas de embarazos con restricción de crecimiento intrauterino idiopática y 19 controles. Se real izó examen macroscópico e histológico, y análisis de la expresión de factor tisular y trombomodulina a nivel de A R N m por PCR en tiempo real y proteínas por ELISA. R esultados. Se evidenció compromiso hemostático en las placentas de embarazos con restricción de crecimiento intrauterino idiopática, siendo la trombosis de los vasos coriales el hallazgo histológico más importante. Se encontró aumento en la expresión de la proteína del factor tisular $(p=0,0411)$ y en la razón de factor tisular/trombomodulina a nivel de A R N m $(p=0,0411)$ y proteína ( $p=0,0215)$. No hubo diferencias estadísticamente significativas entre los grupos en los niveles de A R N m de factor tisular o trombomodulina, ni de trombomodulina a nivel de proteína. Conclusión. Se presenta evidencia de alteración de los mecanismos hemostáticos de la placenta, incluyendo la expresión anormal de factor tisular y de la razón factor tisular/trombomodulina, en embarazos complicados con restricción del crecimiento intrauterino idiopática.

Palabras clave: restricción del crecimiento intrauterino, factor tisular, trombomodulina, enfermedades placentarias 


\section{Resumo}

Alteração dos mecanismos hemostáticos da placenta em restrição de crescimento intra-uterino idiopático. A restrição do crescimento intra-uterino é uma complicação da gravidez com alta probabilidade de morbidade e mortal idade perinatal, que parece ser causada pelo desenvolvimento anormal da vascul atura placentária. Os processos hemostáticos são importantes para o desenvolvimento da placenta, e o desequilíbrio entre fatores pró-coagulantes e anticoagulantes têm sido associadas com a restrição de crescimento intra-uterino. Objetivo. A valiar o compromisso hemostático na placenta com gestações complicadas com restrição de crescimento intra-uterino idiopático. M ateriais e métodos. Foram estudadas cinco placentas de gestações com restrição de crescimento intra-uterino idiopático e 19 controles. Foi realizada uma análise macroscópica e histológica e análise da expressão do factor tecidual e trombomodulina em A R N m por PCR em tempo real e de proteína pelo método de ELISA. R esultados. Foi evidente o compromisso hemostático nas placentas de gestações com restrição de crescimento intra-uterino idiopático; a trombose dos vasos coriônicos é o descobrimento histológico mais importante. A umentaram a expressão de proteína do fator tecidual $(p=0,0411)$ e a proporção do fator tecidual/ trombomodulina ao nível de ARNm $(p=0,0411)$ e de proteína ( $p=0,0215)$. Não houve diferenças estatisticamente significativas entre os grupos nos níveis de ARNm do fator tecidual ou trombomodulina, nem de trombomodulina ao nível de proteína. Conclusão. Se apresenta evidência de alteração dos mecanismos hemostáticos da placenta, incluindo a expressão anormal de fator tecidual e da proporção do fator tecidual/ trombomodulina, em gestações complicadas com restrição de crescimento intra-uterino idiopático.

Palavras-chave: restrição de crescimento intra-uterino, fator tecidual, trombomodulina, doenças da placenta

\section{Introduction}

Intrauterine Growth Restriction (IUGR) is defined as the clinical diagnosis in which the foetus does not reach its full potential growth and the final outcome is a decrease in body weight, being bel ow the $10^{\text {th }}$ percentile for gestational age and sex according to growth charts (1). This condition appears to be due, among other causes, to abnormal placental vasculature caused by alteration of early events in pregnancy and trophoblastic invasion and angiogenesis, ultimately leading to placental vascular insufficiency (2). The placenta is a highly vascular organ that functions as an interface between foetal blood and maternal blood. It is the main regulator of human pregnancy that is involved in basic functions such as metabolism, nutrient transfer, gas exchange and endocrine secretion (2-4). A lso it plays an essential role in maintaining pregnancy and promoting normal embryonic and foetal development (2). Reported in the literature are findings in pre-eclampsia and IU GR with or without preecl ampsia that suggest si milar pathophysiological mechanisms $(4,5)$. In pre-eclampsia (PE) and IU GR, the trophoblast is proliferative and less invasive, leading to a superficial invasion of uterine spiral arteries and therefore an increased uteroplacental resistance. Subsequently, these events lead to impaired uteroplacental perfusion and deficiency in maternal-foetal transport of nutrients and oxygen (4). A bnormal vascular structure of placenta associated with increased risk of utero-placental thrombosis has been described for IU G R (5). The increased turbulence in the intervillous space may damage the syncytium and increase perivillous fibrin deposition, so both the chronic injury of the perfusion of the placenta and/or nutritional deprivation could eventually lead to impaired development of the villi (5).
The structure of the placenta requires efficient mechanisms for fast and local regulation of coagulation, so that the presence of procoagulant and anticoagul ant factors produced by both endothelial cells and trophoblast is important in haemostasis (3). Tissue Factor (TF) is a glycoprotein and membrane receptor that plays an important role in mediating the cellular initiation of the extrinsic pathway of coagulation through the activation of factor VII, which is the main coagulation pathway in the placenta (6). The TF also plays an important role in the development and maintenance of blood vessels as well as in cell signalling and inflammatory pathways, and it is probable that it may also play a role in the placenta acting on coagulation and as a regulator of growth and differentiation of blood vessels $(3,7,8)$. The abnormal expression of this molecule has been associated with PE and is probably involved in IU GR (7). It has been shown that in placentas from pregnancies with $P E$ there is an increase of TF expression $(6,9,10)$. This increase may contribute to the formation of fibrin deposition and occlusive injuries and may participate in the thrombotic complications associated with PE (11). A $n$ aberrant expression of TF in the decidual endothelium has been reported in IU GR (12). Thrombomodulin (TM ) is a membrane protein that generates no covalent complexes with thrombin (13). In placenta, TM is expressed in trophoblast and foetal and maternal capillary endothelium (14). TM may act as an anticoagulant when bound to thrombin and activated protein $\mathrm{C}$, but also as an anti-fibrinolytic by activation of the Thrombin-A ctivatable Fibrinolysis Inhibitor (TA FI). High levels of TA FI have been associated with thrombotic tendency. This dual effect of TM can modulate the growth of the placenta because activated protein $C$ regulates the proliferation of the trophoblast and an impaired fibrinolytic activity may protect the trophoblast of apoptosis induced by fibrin degradation products $(3,8)$. 
Increased levels of TM protein in the vessels of the placentas have been reported in IUGR, with statistically significant differences compared to the control group (15). There are no reports in the literature about Colombian studies evaluating the expression of TF and/or TM in placentas from pregnancies complicated by IU GR. W e present here the results of an initial approach in Colombian samples. According to previous data in the literature we propose that there are changes in local haemostasis in the placenta of pregnancies complicated by IUGR.

Finally, it is necessary to study the mechanisms involved in alterations of the placenta, especially in the generation of thrombo-occlusive injuries in IUGR since the new knowledge produced may allow a better understanding of the pathophysiology of IU GR and may improve management and prognosis of affected foetuses (2).

\section{M aterials and methods}

\section{Sample collection}

A case control type study was conducted with pregnant women in their third trimester whose pregnancies coursed with idiopathic IU GR and pregnant women with healthy foetuses and without pregnancy complications, assisted by the Department of Gynecology and Obstetrics of the Hospital U niversitario San I gnacio in B ogotá (Colombia), between November 2009 and December 2010. The inclusion criteria were patients with ultrasonographic diagnosis of IUGR (estimated foetal weight below the $10^{\text {th }}$ percentile for gestational age and sex), according to the WHO (W orld Health Organization) criteria, and small for gestational age newborn (neonate's birth weight below the $10^{\text {th }}$ percentile for gestational age and sex) with no apparent aetiology (16). We excluded patients with ul trasonographic diagnosis of IU GR who were small for gestational age with known cause, foetus / new born with major foetal malformations or diagnostic impression of genetic disease, pregnant women with prothrombotic conditions, and those who expressed their desire not to participate in the study. The study was approved by the Committee for Research and Bioethics of the M edical School of the Pontificia U niversidad Javeriana, which meets the guidelines established in the Declaration of Helsinki of 1975 and amended in 2004. A II participants filled out a voluntary informed consent. A triangular sample of tissue of paracentral placenta was taken that was about $2 \mathrm{~cm}$ on each side immediately after delivery and stored in a $2.0 \mathrm{ml}$ tube with $500 \mu \mathrm{l}$ of RNA Later (Qiagen, Chatsworth, CA) at $-40^{\circ} \mathrm{C}$ until processed.

\section{A natomical-pathological study}

After taking the above mentioned samples, a foetal pathologist performed a conventional study of the placentas, observing all segments. Three plate cuts were taken with chorion and decidua far from the edge, randomly but including thicker and thinner areas, two roll cuts of membranes and two cuts of cord. Paraffin- embedded placental tissues were stained with hematoxylin-eosin. $M$ acroscopic and microscopic evaluation of the placenta was aided by filling out a checklist with (a) macroscopic parameters: insertion and length of the cord, number of vessels in the cord, placental weight, presence of hematoma on the maternal surface, coloration of fetal surface, placental thicknesses, maternal infarction, insertion and color of fetal membranes and number of cotyledons; (b) microscopic parameters: changes of decidual vessels, location of fibrinoid depositions, location of placental hematoma, location and age of thrombus, number of villi vessels, presence of normoblasts and necrosis in the villi. The pathologist was blinded to foetal diagnosis and molecular results for histopathologic evaluation. We determined the percentage of deposits of fibrin thrombi in the foetal circulation, the vascular alterations in the maternal vessels and changes in chorionic villi; additionally, there were other changes that could be found.

\section{Extraction and quantification of proteins}

Quantification of TF and TM proteins was performed by ELISA (enzyme-linked immunoassay) with the IMUBIND ${ }^{\circledR}$ T issueF actorELISA kitand thrombomodulin IM UBIND (B) K it (A merican Diagnostica Inc, Framingham, MA, USA) following the manufacturer's recommendations. Briefly, $75 \mathrm{mg}$ of frozen tissue were weighted and pulverized, then $1.8 \mathrm{ml}$ of TBS at pH 8.5 were added, and $0.2 \mathrm{ml}$ of $10 \%$ Triton $\mathrm{x}-100$ (Sigma-A Idrich, St. Louis, M issouri, USA) in TBS at pH 8.5 were finally added. The mix was stirred for 12 hours at $4^{\circ} \mathrm{C}$. The suspension was centrifuged at $100,000 \mathrm{rpm}$ for 60 minutes at $4^{\circ} \mathrm{C}$ to remove cellular debris. Extraction and quantification of total protein was performed with the GeneQuant pro (A mersham Bioscience, Piscatoway, N), USA) equipment and aliquoted in portions of $100 \mu \mathrm{l}$. Thereafter, the extracted proteins were incubated in wells with capture antibodies. A fter capture, the TF or the TM was detected using a biotinylated antibody that specifically binds to the target protein. Subsequently horseradish peroxidase was added conjugated with streptavidin (HRP) to complete the complex formation of antibody-enzyme detection. The levels of TF and TM were determined by measuring the absorbance at $450 \mathrm{~nm}$ and determining the values using a standard curve. Concentrations are reported as pg / mg of total protein. 


\section{R NA extraction and real time PCR (qRT-PCR)}

A fter weighing $75 \mathrm{mg}$ of tissue, total RNA was extracted from placental tissue using Trizol (Invitrogen L ife Technologies, Carlsbad, CA, USA) by modifying the manufacturer's instructions. B riefly, $75 \mathrm{mg}$ tissue were added to $500 \mu \mathrm{l}$ of lysis solution (0.025M EDTA, SDS $2 \%)+16 \mu$ of proteinase $\mathrm{K}(20 \mathrm{mg} / \mathrm{ml})$ (Sigma-A ldrich, St. L ouis, M issouri, USA) to ensure cell lysis and release of RNA and allowed to incubate at $56^{\circ} \mathrm{C}$ for 48 hours. Then, $1 \mathrm{ml}$ of TRIzol LS (Invitrogen Life Technologies, Carlsbad, CA, USA) was added and incubated at room temperature for 5 minutes. L ater, $200 \mu \mathrm{l}$ of chloroform (Sigma-A Idrich, St. Louis, M issouri, USA) were then added, with vigorous stirring and the mixture was al lowed to incubate at room temperature for 3 minutes. It was then centrifuged at $13,500 \mathrm{~g}$ for 15 minutes at $4^{\circ} \mathrm{C}$. The aqueous phase was passed to another tube and 500 $\mu$ of isopropyl alcohol were added and then washed with $500 \mu \mathrm{l}$ of $75 \%$ ethanol. The substance was resuspended in $50 \mu$ of DEPC water, and was incubated at $56^{\circ} \mathrm{C}$ for 10 minutes. It was quantified by spectrophotometry in a GeneQ uant pro spectrophotometer (A mersham Bioscience, Piscatoway, N J, USA ) and $5 \mu \mathrm{g}$ of RNA was incubated with $5 \mathrm{U}$ of DNase I (Epicentre, Madison, WI, USA) at $37^{\circ} \mathrm{C}$ for 30 minutes. The result was then re-quantified to ensure the removal of DNA. The substance was finally stored at $-40^{\circ} \mathrm{C}$. One microgram of total RNA was used for reverse transcription with random primers using the kit I mPromII Reverse Transcription System (Promega, M adison, WI, USA). LigthL ycler thermocycler was used (Roche A pplied Bioscience, Indianapolis, IN , USA) with SY BR Green system (LigthCycler FastStart DNA M aster SY BR Green I kit, Roche) and software for quantification of Lightcycler 4.1 (Roche A pplied B ioscience, Indianapolis, IN, USA). The PCR was performed in a reaction volume of $20 \mathrm{ml}$ with $5 \mu \mathrm{l}$ of sample, $1.5 \mathrm{mM} \mathrm{M} \mathrm{gCl}{ }_{2}$, 1x buffer and $0.25 \mathrm{mM}$ of primers, following the manufacturer's recommendations. The PCR was performed using the following initial denaturation parameters: $95^{\circ} \mathrm{C}$ for $10 \mathrm{~min}$ 45 cycles of denaturation: $95^{\circ} \mathrm{C}$ for 10 seconds, annealing depends on the primers (TF and TM: $62^{\circ} \mathrm{C}$. GAPDH: $60^{\circ} \mathrm{C}$ ) for 10 seconds, elongation: $72^{\circ} \mathrm{C}$ for 10 seconds and melting curve: $60-90^{\circ} \mathrm{C}$. The sequences of the primers are: TF: forward AATGTGGAGAGCACCGGTTC reverse CGTTCATCTTCTACGGTCACATTC TM: forward: TAACGAAGACACAGACTGCGATT, reverse: CTAGCCCACGAGGTCAAGGT; GAPDH: forward: CACGGCAAGTTCAACGGC, reverse: GGTGGTGAA GACGCCA GTA. A n absolute quantification analysis was performed of TM and TF gene expression normalizing with the GAPDH gene. The calibration curve was made from the PCR product purified with the W izard ${ }^{\circledR}$ SV G el and PCR Clean-U p System (Promega, M adison, WI, USA), the concentration of copies was calculated according to Overbergh et al. (17). Serial dilutions were performed with a range from $1 \times 10^{7}$ to $1 \times 10^{1}$ copies. Each sample was analyzed in duplicate and each analysis was mounted in a negative control in which cDNA instead of water was placed.

\section{Statistical analysis}

Comparison of medians was performed with the MannW hitney test and comparison of frequencies with a binomial exact test. We considered statistical ly significant difference when $p$ value was less than 0.05 . We used Stata 9.1 and GraphPad Prism 4 softwares.

\section{Results}

\section{Characteristics of the study population}

We assessed 5 cases and 19 controls. For this study, women who underwent caesarean section were selected to avoid labour-related haemostatic changes. A s for the characteristics of the study population, $60 \%$ of the cases were classified as symmetrical IU GR and $40 \%$ as asymmetric IU GR, $80 \%$ were bel ow the 5th percentile for gestational age, $40 \%$ had abnormal Doppler ultrasound of the flow in uterine arteries. In $60 \%$ of the cases, they were women and $40 \%$ were men, the controls showed that they were $63.16 \%$ and $36.84 \%$ respectively. Other characteristics are presented in table 1.

Table 1. Description of the study population

\begin{tabular}{|c|c|c|c|c|}
\hline & M aternal age (years) & G estational age (weeks) & W eigth at birth (g) & Size at birth (cm) \\
\hline Cases & $29.00(20-34)^{*}$ & $37.00(31-40)$ & $2145.00(895-2775)$ & $47.00(33-48)$ \\
\hline Controls & $29.00(22-38)$ & $38.00(37-42)$ & $2965.00(2470-3460)$ & $48.00(45-52)$ \\
\hline P value & 0.5678 & 0.2239 & 0.0062 & 0.1285 \\
\hline
\end{tabular}

$*$ D ata are presented as median (min-max range) of each variable. 


\section{H istopathological findings}

The macroscopic analysis showed that all cords had three vessels. As for the weight of the placenta, the median of the cases was $460 \mathrm{~g}$ (range: 290-475) and of controls was $470 \mathrm{~g}(390-610)$, with no statistically significant difference ( $p=0.3731$ ). Regarding the index of the placental weight/ birth weight ratio, it was $1 / 4.65$ (Range: $1 / 3.09-1 / 5.78$ ) and controls were $1 / 6.12$ (1/5.49-1/8.09), with statistically significant differences $(p=0.0020)$. As for the microscopic analysis, it showed an increase of chorionic vessel thrombosis in the placentas of the cases compared with controls, with statistically significant differences. The analysis of the simultaneous occurrence of chorionic vessel thrombosis and increased perivillous deposits show ed statistically significant differences. There were no decidual arteriopathies, massive deposits of fibrin on the maternal floor or villous necrosis in any of the cases and controls (T able 2, figure 1 ).

\section{Protein evaluations for TF and TM}

TF expression in the cases was 2.36 fold higher than in controls. The median concentration of TF in the cases was 2,244.75 (Range: 933.74-3585.72) pg/mg protein and 952.70 (Range: $360.69-5721.59$ ) pg/mg protein in controls, with statistically significant differences $(p=0.0411)$. The concentration of TM protein in the cases was $2,865.82$ $\mathrm{pg} / \mathrm{mg}$ and in controls was $3,701.10 \mathrm{pg} / \mathrm{mg}$, but showed no statistically significant differences $(p=0.3491)$. TM expression at protein level in the control group was 1.29 fold that of the cases. The ratio in concentrations of $T F$ and TM (TF/TM ) in placental extracts was 0.90 in the cases and 0.24 in controls, with statistically significant differences $(p=0.0215)$. There was an increase of the TF/TM ratio of 3.69 fold in the cases respect to the controls (Figure 2).

\section{TF and TM mRNA assessment}

The cases showed 1.76 fold more expression than the controls. The median of TF mRNA by relative quantification was 0.66 (Range: $0.11-2.82$ ) in the cases and in the controls it was 0.38 (Range: $0.02-1.43$ ), with no statistically significant differences $(p=0.3491)$. A s for the relative expression of TM, for controls it was 6.65 fold the expression of GA PDH, whereas in the cases it was 4.73 fold the expression of GAPDH, demonstrating expression of TM in controls 1.41 fold greater than the expression of cases, with no statistically significant differences $(p=0.4436)$. The relationship in concentrations of TF and TM (TF/TM) mRNA levels in placental extracts of the cases was 0.23 and 0.05 in controls; there was an increase in the TF $/ \mathrm{M}$ M ratio which was 4.68 fold higher in the cases compared to the controls, with statistically significant differences $(p=0.0411)$ (Figure 3).

\section{Discussion}

IU GR is a complication of pregnancy whose study generates great interest in the medical and scientific community due to its importance in perinatal morbidity and mortality

Table 2. M icroscopic findings in the histopathological evaluation of the placenta.

\begin{tabular}{lccc}
\hline \multicolumn{1}{c}{ Finding } & $\begin{array}{c}\text { Cases } \\
\mathbf{n}(\%)\end{array}$ & $\begin{array}{c}\text { Controls } \\
\mathbf{n}(\%)\end{array}$ & p value \\
\hline Vascular thrombosis & $4(80.0)$ & $6(31.6)$ & 0.0390 \\
\hline Chorionic vessel thrombosis & $4(80.0)$ & $4(21.1)$ & 0.0081 \\
\hline Thrombosis of cord vessels & $0(0.0)$ & $3(15.8)$ & 1.0000 \\
\hline Increased perivillous fibrin deposits* & $3(60.0)$ & $4(21.1)$ & 0.0663 \\
\hline Placental haematoma & $1(20.0)$ & $2(10.5)$ & 0.4263 \\
\hline Normoblasts & $4(80.0)$ & $9(47.4)$ & 0.1562 \\
\hline Leukocyte stasis & $2(40.0)$ & $2(10.5)$ & 0.0891 \\
\hline Syncytium hyperplasia & $2(40.0)$ & $6(31.6)$ & 0.5038 \\
\hline Edema & $2(40.0)$ & $4(21.1)$ & 0.2843 \\
\hline Cyst X & $1(20.0)$ & $4(21.1)$ & 0.6932 \\
\hline$>10$ villous vessels & $1(20.0)$ & $1(5.3)$ & 0.2367 \\
\hline $\begin{array}{l}\text { Chorionic vessel thrombosis +increased perivillous } \\
\text { fibrin deposits }\end{array}$ & $3(60.0)$ & $2(10.5)$ & 0.0098 \\
\hline
\end{tabular}

* Defined as more than $15 \%$ 
a.
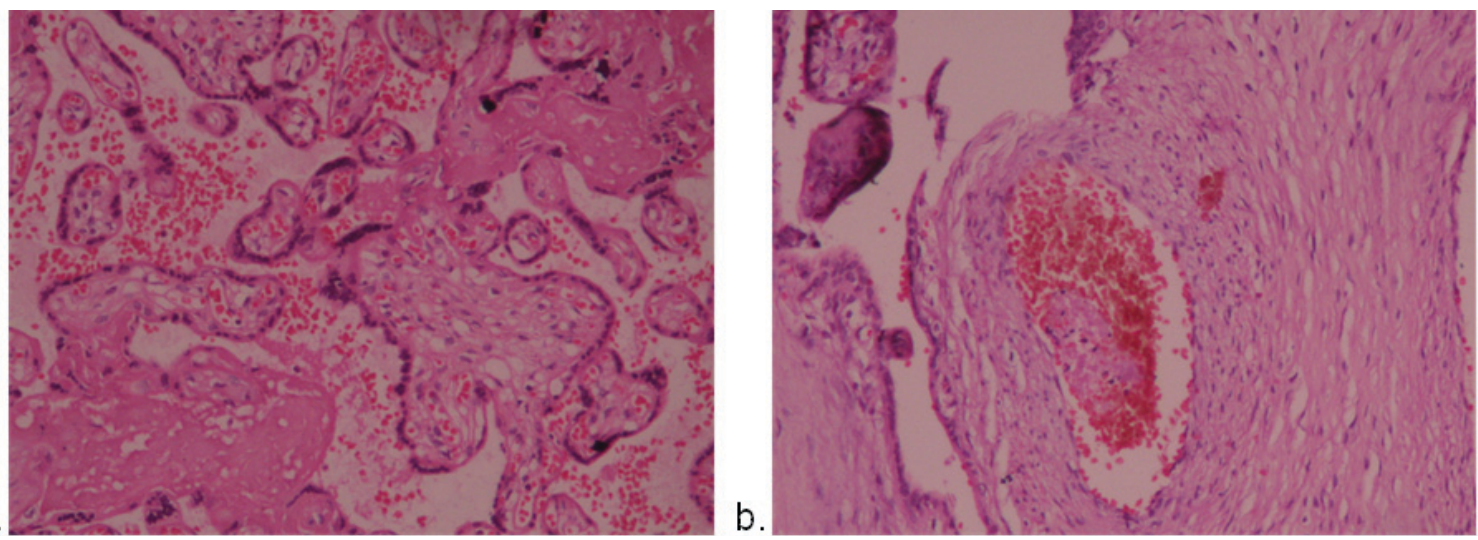

Figure 1. Histopathological findings of an IUG R placenta in paraffin- embedded tissue. a. Perivillous deposits of fibrin. $b$. Chorionic vessel thrombus. Hematoxylin-eosin staining, X 40.
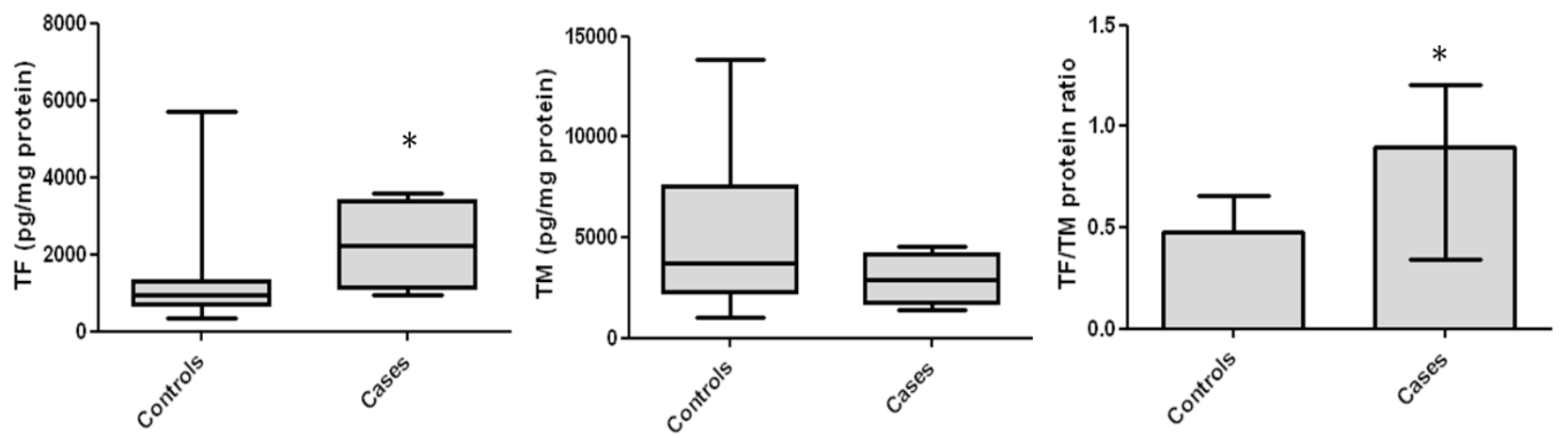

Figure 2. Protein levels measured in placentas from the cases and the controls. The results are expressed in $\mathrm{pg} / \mathrm{mg}$ of total protein. TF (left), TM (middle) and TF / TM ratio (right). *p value $<0.05$.
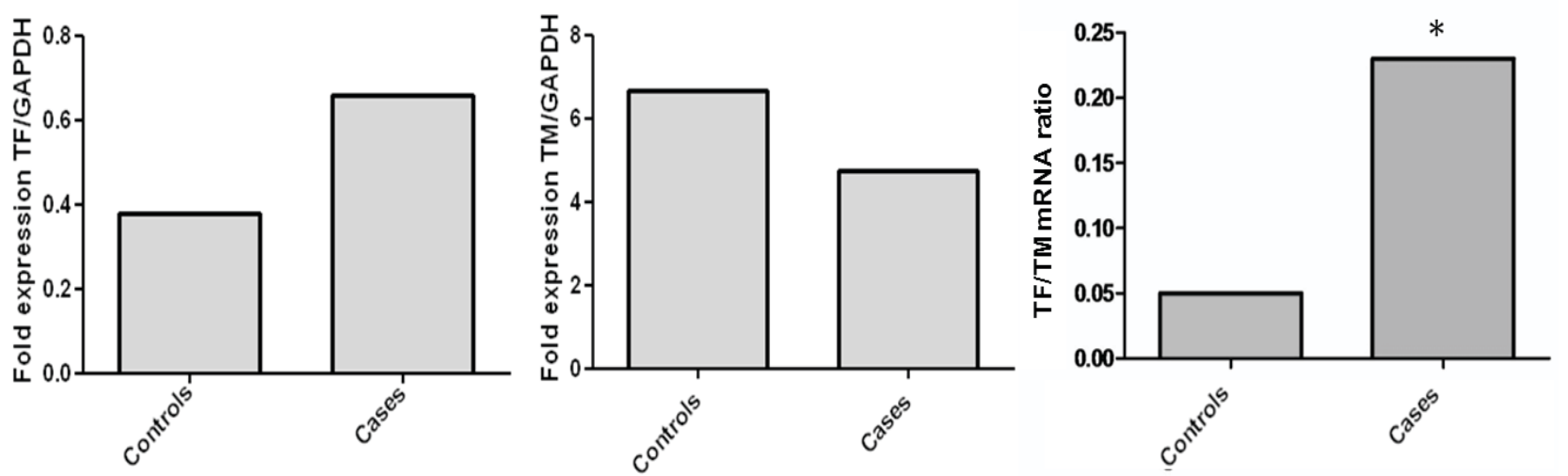

Figure 3. R elative expression of mR NA measured in placentas from cases and controls. TF (left), TM (middle) and TF/TM ratio (right) with respect to GAPDH. *p value<0.05. 
(18). The difference in the placental weight/birth weight ratio between cases and controls, together with the finding that indicates no differences in placental weight between the groups tested, shows compromise of foetal growth but does not compromise the placenta; it is worth noting that the ratio found in controls is similar to that reported in the literature as normal (1/5 to $1 / 6)$ (19). Chorionic vessel thrombosis was the main microscopic finding instead of the increased perivillous fibrin deposits as described in the literature. A lthough fibrin deposits on the syncytial surface are physiological and are also critical components in the repair and differentiation of villi, increased perivillous fibrin deposits are frequent findings in pregnancies complicated by PE or IUGR, and this increase in fibrin deposits could be related to decreased transport of nutrients from mother to foetus (20). In these diseases, it is also common to find placental vascular lesions, findings that could be related to its pathophysiology (18). In our study, therefore, pathological findings demonstrate the local haemostatic compromise that has been described in the literature.

In placenta, the trophoblast cells are characterized by elevated expression of coagulation components, such as $T F$ and TM, which are not only involved in hemostasis, but also in the differentiation of blood vessels of the placenta (21). During pregnancy, the placenta is a major source of TF, as it has been possible to find high levels of this protein in extracts of placental tissue and amniotic fluid (3). The presence of large amounts of ready-to-use TF appears to be relevant to the maintenance of haemostasis in the placenta, but may predispose to placental vascular complications (21). Currently, it has been suggested that reduced uteroplacental blood flow causes decidual hypoxia generating $V$ ascular Endothelial Growth Factor (VEGF) in the perivascular decidua (22); excessive VEGF induces the expression of TF mRNA and protein, and this increase stimulates thrombin generation. Thrombin exacerbates this process by generating greater TF expression, thus promoting uteroplacental thrombosis and inducing the production of inflammatory cytokines and abnormal angiogenesis, which ultimately lead to foetal loss, PE, IUGR and placental abruption (7). There is evidence for this hypothesis; for example, $C$ hinni et al. found an association between levels of TF and VEGF in placentas from pregnancies with PE (23). A dditionally, in the blood vessels in the basal plate of placentas from pregnancies with low birth weight and maternal uteroplacental mal perfusion evidence reported an increase in TF compared with placentas from pregnancies with low birth weight associated with chronic villitis or normal pregnancies; however, these results correspond to immunohistochemical analysis and $p$ value is not reported (12). Furthermore, an increased expression of TF mRNA in the vascular endothelium of the basal decidua of pregnancies complicated by preeclampsia with IUGR has been also reported (24). In our study, statistically significant differences were found between groups at the TF protein but not at mRNA level. These conflicting results may be due to two causes, among others: first, it has been reported that TF mRNA is rapidly degraded because it has A U-rich regions in $3^{\prime}$-end, which have been associated with rapid degradation of RNA (25); the second explanation is that post-transcriptional modifications may occur to regulate protein synthesis. However, the findings from this study plus those reported in the literature suggest that there is altered expression of TF in placenta of IU GR complicated pregnancies (7).

Otherwise, the most important anticoagulant pathway in the placenta is mediated by TM (26). B osco et al. (27) suggest that TM plays an important role in preserving the role of stromal myofibroblasts in villous contractility and modulation of the intervillous spaces affecting both foetal and maternal circulation $(28,29)$. These results suggest that in $P E$, the decrease in blood flow may be due to functional impairment and structural villous vessel endothelium, whereas increased expression of TM and perivascular stromal myofibroblasts surrounding the villi could have a compensatory effect of prothrombotic changes and modulate blood flow in the foetal villous tree (27). The results of our study are consistent with those reported by Wienhard et al., who showed by immunohistochemistry an increased expression of TM in chorionic vessels of placentas in pregnancies complicated with IUGR (15).

It is worth noting that both $T F$ and $T M$, the expression analysis of mRNA, normalized with GAPDH as standard housekeeping gene and non-normalized, showed a positive correlation of 0.84 and 0.83 , respectively $(p<0.0001$ for both). This result suggests that the sample processing and experimental protocols did not interfere with the results.

Furthermore, since 1993 publications have been showing the relationship between the regulatory mechanisms of the expression of TF and TM in different in vitro models. In 1993, B artha et al. showed that thrombin regulates the expression and activity of TF and TM in endothelial cells of human saphenous vein (25). Koyama et al. reported that trans retinoic acid increases the expression of TM and reduces TF expression in human leukemia cells (30). These findings suggest that TF and TM share regulatory mechanisms. Similarly, in 1999 Zhu et al. reported that the procoagulant activity of human leukemia cells was dependent on the amount of protein from TF, but principally because of the ratio in the amount of TF and TM antigens on the cell membrane (TF/TM ) (31). These findings that indicate the relationship between TM and TF expression 
and its role in cellular procoagulant activity encouraged us to analyze the TF/TM ratio at mRNA and protein level. On this point, the results found in our study with the evidence described above, suggest that the TF/TM ratio could serve as a marker, possibly better than the individual results of local compromise of the major procoagulant and anticoagulant mechanisms in the placenta of pregnancies that occur with idiopathic IU GR. It is also important to note that studies on the expression of TF and TM using samples of placenta of pregnancies complicated by preeclampsia showed similar results to those reported here for idiopathic IU GR (A yal a $P$, Garcia-R obles R, B ermúdez M , B ernal J , Fornes A, Illanes S. Unpublished data).

There are no reports in the literature showing compromised TF expression in placentas with idiopathic IUGR. Likewise, we did not find reports of studies evaluating the ratio TF/ $T M$, so this is the first study that shows alteration of this ratio in IU GR placentas.

A lthough the stringent selection of cases and controls was a restraint for a larger sample size, it is also true that the introduction of confounding variables was better controlled. We recommend increasing the sample size while maintaining rigor in the selection of cases and controls for a better estimation of the variables and their role in IU GR. However, it should be noted that despite the small sample size and analysis with non-parametric tests we found statistically significant differences that suggest alteration of local haemostasis with involvement in the expression of TF and $T F / T M$ ratio in placentas of pregnancies complicated by IUGR. A dditionally, we propose immunohistochemical studies to identify and evaluate differences in expression of TF and TM, as well as in vitro studies of trophoblast under hypoxic conditions to evaluate expression at $\mathrm{mRNA}$ and protein levels.

\section{Conclusion}

The evidence suggests that there are al terations in haemostatic mechanisms in the placentas of pregnancies occurring with IUGR, but more studies are needed to elucidate how early these changes occur and whether they could serve as early markers of development of IUGR, and consider the implications that these findings have for proposals in the prediction and prevention, as well as an adequate and timely management of IU GR. In PE it has been described that treatment with low doses of aspirin reduces the incidence in women at high risk (32) and it is possible that this and other strategies to treat the imbalance in coagulation in IU GR al so may have a beneficial impact. It is worth noting that despite the difficulties inherent in such studies as sampling and its performance, positive and relevant results were achieved to get a better understanding of the pathophysiological mechanisms involved in idiopathic IUGR. These results encourage us to continue this research and get a better estimation of these parameters. Finally, we believe the study of the role of TF, TM and the TF/TM ratio in pathologies such as IU GR and PE could generate knowledge about their pathophysiology with a potential impact on prevention, diagnosis, prognosis and treatment of these diseases.

\section{Acknowledgements}

The authors thank Dr. Fabián Gil for the advice in the statistical analysis, the $\mathrm{Obstetrics}$ and Gynecology service at Hospital U niversitario San I gnacio and pregnant women who participated in the study.

\section{Financial support}

This work was financially supported by the Academic $V$ ice-Rectorate of the Pontificia U niversidad J averiana.

\section{Conflict of Inter est}

We declare no conflict of interest that may affect the content, results or conclusions of the article with the institution that sponsored the research or where research was done.

\section{R eferences}

1. M uñoz M olina L, Hernández Barbosa R. R etardo de crecimiento intrauterino (RCIU) y sus alteraciones bioquímicas. NOVA 2005; 3(3): 88-94.

2. B aykal C, Sargon M F, Esinler I, Önderoglu S, Önderoglu L. Placental microcirculation of intrauterine growth retarded fetuses: scanning electron microscopy of placental vascular casts. Archives of $\mathrm{G}$ ynecology and $\mathrm{O}$ bstetrics. 2004; 270(2): 99-103.

3. Lanir N, A haron A, B renner B. Procoagulant and anticoagulant mechanisms in human placenta. 2003. Seminars in Thrombosis and Hemostasis. 2003; 29(2): 175-184.

4. M ayhew TM, Ohadike C, B aker PN , Crocker IP, M itchell C, Ong SS. Stereological investigation of placental morphology in pregnancies complicated by pre-eclampsia with and without intrauterine growth restriction. Placenta. 2003; 24(2-3): 219-226.

5. Salafia CM, Charles AK, M aas EM. Placenta and fetal growth restriction. Clinical 0 bstetrics and Gynecology. 2006; 49(2): 236-256. 
6. Teng $Y C, L$ in $Q D$, Lin JH, Ding CW , Zuo Y. Coagulation and fibrinolysis related cy tokine imbalance in preeclampsia: the role of placental trophoblasts. J ournal of Perinatal M edicine. 2009; 37(4): 343-348.

7. K rikun G, Lockwood CJ, Paidas M J. Tissue factor and the endometrium: from physiology to pathology. Thrombosis Research. 2009; 124(4): 393-396.

8. Rousseau A, Favier R, V an Dreden P. Elevated circulating soluble thrombomodulin activity, tissue factor activity and circulating procoagulant phospholipids: $\mathrm{New}$ and useful markers for pre-eclampsia? European J ournal of O bstetrics, G ynecology, and Reproductive Biology. 2009; 146(1): 46-49.

9. Estellés A, Gilabert J, K eeton $M$, Eguchi $Y, A$ znar J, Grancha S, Espña F, L oskutoff DJ, Schleef RR. Altered expression of plasminogen activator inhibitor type 1 in placentas from pregnant w omen with preeclampsia and/or intrauterine fetal growth retardation. Blood. 1994; 84(1): 143-150.

10. Teng $Y$, J iang $R$, L in $Q$, Ding $C, Y e Z$. The relationship between plasma and placental tissue factor, and tissue factor pathw ay inhibitors in severe pre-eclampsia patients. Thrombosis Research. 2010; 126(1): e41-45.

11. López-Ramírez $Y$, Carvajal Z, A rocha-Piñango CL. Parámetros hemostáticos en placenta de pacientes con embarazo normal y con preeclampsia severa. Investigación Clínica. 2006; 47(3): 233-240.

12. Krikun G, Huang ST, Schatz F, Salafia C, Stocco C, Lockwood CJ. Thrombin activation of endometrial endothelial cells: a possible role in intrauterine growth restriction. Thrombosis and Haemostasis. 2007; 97(2): 245-253.

13. Rivero ZR. Caracterización de la trombomodulina, un anticoagulante natural. Revista Cubana de Angiología y Cirugía Vascular. 2000; 1(2): 118-124.

14. Fazel $A, V$ incenot $A, M$ alassiné $A$, Soncin $F, G$ aussem $P$, A lsatE, Evain-B rion D. Increase in expression and activity of thrombomodulin in term human syncytiotrophoblast microvilli. Placenta. 1998; 19(4): 261-268.

15. W ienhard J, B ielska B, M ünstedt K, L ang U, Zygmunt M . Increased endothelial thrombomodulin (TM ) expression in pregnancies complicated by IU GR. J ournal of Perinatal M edicine. 2002; 30(4): 322-328.

16. Consulta M ixta de Expertos OM S/FA O. D ieta, nutrición y prevención de enfermedades crónicas. Ginebra: Organización M undial de la Salud. 2003. p. 1-86.

17. Overbergh L, Valckx D, Waer $M, M$ athieu $C$. Quantification of murine cytokine mRNAs using real time quantitative reverse transcriptase PCR. Cytokine. 1999; 11(4): 305.

18. M any A, Schreiber L, Rosner S, Lessing J B, Eldor A, K upferminc MJ. Pathologic features of the placenta in women with severe pregnancy complications and thrombophilia. 0 bstetrics and G ynecology. 2001; 98(6): 1041-1044.

19. Bajo A renas J, M elchor $M$ arcos J C and M ercé $L T$. F undamentos de 0 bstetricia (SE G O). M adrid: Gráficas M arte SL; 2007.p. 1-1162.

20. Guller S. Role of the syncytium in placenta-mediated complications of preeclampsia. Thrombosis Research. 2009; 124(4): 389-392.

21. B renner B. Haemostatic changes in pregnancy. Thrombosis Research. 2004; 114(5-6): 409-414.

22. Lockwood C], Toti P, Arcuri F, Norwitz E, Funai EF, H uang ST, B uchwalder LF, K rikun G, Schatz F. Thrombin regulates soluble fms-like tyrosine kinase-1 (sFlt-1) expression in first trimester decidua: implications for preeclampsia. The American J ournal of Pathology. 2007; 170(4): 1398-1405.

23. Chinni $E$, Colaizzo D, Margaglione $M$, Rubini $C$, D'A mbrosio RL, Giuliani F, Di Vagno G, Grandone E. Correlation between factors involved in the local haemostasis and angiogenesis in full term human placenta. Thrombosis Research. 2008; 122(3): 376-382.

24. Di Paolo S, V olpe P, G randaliano G, Stallone G, Schena A, Greco P, Resta L, Selvaggi L, Cincione R, Schena FP, Gesualdo L. Increased placental expression of tissue factor is associated with abnormal uterine and umbilical D oppler waveforms in severe preeclampsia with fetal growth restriction. J ournal of Nephrology. 2003; 16(5): 650-657.

25. Bartha K, Brisson C, A rchipoff G, de la Salle C, Lanza $F$, Cazenave JP, Beretz A. Thrombin regulates tissue factor and thrombomodulin mRNA levels and activities in human saphenous vein endothelial cells by distinct mechanisms. The J ournal of Biological C hemistry. 1993; 268(1): 421-429.

26. Dittman WA, Majerus PW. Structure and function of thrombomodulin: a natural anticoagulant. Blood. 1990; 75(2): 329-336.

27. Bosco C, Parra M, Barja P, Rodrigo R, Fernández V, Suarez $M, M$ uñoz $H$. Increased immunohistochemical expression of thrombomodul in at placental perivascular myofibroblast in severe preeclampsia (PE). H istology and H istopathology. 2005; 20(4): 1045-1055.

28. Demir R, Kosanke G, Kohnen G, Kertschanska S, $K$ aufmann $P$. Classification of human placental stem villi: 
review of structural and functional aspects. Microscopy Research and Technique. 1997; 38(1-2): 29-41.

29. Kacemi A, V ervelle C, U zan S, Challier J C. Immunostaining of vascular, perivascular cells and stromal components in human placental villi. Cellular and Molecular Biology (Noisy-le-Grand, F rance). 1999; 45(1): 101-113.

30. K oyama T, Hirosawa S, K awamata N, Tohda S, A oki $\mathrm{N}$. All-trans retinoic acid upregulates thrombomodulin and downregulates tissue-factor expression in acute promyelocytic leukemia cells: distinct expression of thrombomodulin and tissue factor in human leukemic cells. Blood. 1994; 84(9): 3001-3009.
31. Zhu J, Guo WM , Y ao YY, Zhao WL, Pan L, Cai X, Ju $B$, Sun GL, W ang HL, Chen SJ , Chen GQ, Caen J, Chen $Z, W$ ang $Z Y$. Tissue factors on acute promyelocytic leukemia and endothelial cells are differently regulated by retinoic acid, arsenic trioxide and chemotherapeutic agents. Leukemia: 0 fficial J ournal of the Leukemia Society of America, Leukemia Research F und, U .K. 1999; 13(7): 1062-1070

32. Ruano R, Fontes RS, Zugaib M . Prevention of preeclampsia with low-dose aspirin: a systematic review and metaanalysis of the main randomized controlled trials. Clinics (São Paulo, Brazil). 2005; 60(5): 407-414. 